\title{
HUMAN RIGHTS AND PARLIAMENTARY SOVEREIGNTY IN NEW ZEALAND
}

Petra Butler*

The paper examines whether there was any basis for Parliament to enact section 3(2) of the Supreme Court Act 2003 in regard to human rights decisions of the Court of Appeal. The paper asks whether the Court of Appeal has indeed been "activist" in its human rights decisions. The discussion focuses on the areas where judicial activism might be suspected, firstly the filling of legislative gaps, and secondly statutory interpretation, with a special focus on implied repeal. Relevant decisions of the House of Lords under the Human Rights Act 1998 (UK) are used as a contrast to the decisions of the New Zealand Court of Appeal. The paper comes to the conclusion that the New Zealand Court of Appeal has not been activist in the area of human rights.

Cet article examine dans quelles mesures, après les positions prises par la Cour d'Appel néozélandaise relative aux droits de l'homme, le Parlement de ce pays pouvait légitimement promulguer l'article 3(2) du Supreme Court Act 2003. L'auteur s'intéresse au rôle joué par cette haute juridiction et aux conséquences supposées ou réelles que cela a pu avoir sur l'élaboration des droits de l'homme en Nouvelle Zélande. Il constate que cet apparent «activisme» judiciaire est d'autant plus marqué chaque fois qu'un vide législatif existe ou encore lorsque la Cour d'Appel néo-zélandaise met en oeuvre son pouvoir d'interprétation des règles existantes. A l'appui de l'analyse, une comparaison est alors opérée entre les décisions rendues par la Chambre des Lords sur le fondement du UK Human Rights Act 1998 et celles de la Cour d'appel néo-zélandaise. L'auteur en conclu qu'en ce qui concerne les droits de l'homme, la plus haute juridiction néozélandaise n'a jamais vraiment joué un rôle aussi fondamental que les apparences pourraient le laisser penser.

\section{INTRODUCTION}

Section 3(2) of the Supreme Court Act 2003 states that "[n]othing in this Act affects New Zealand's continuing commitment to the rule of law and the sovereignty of parliament".

Readers of this section might immediately ask why Parliament felt compelled to state the obvious. How could the Act establishing a Supreme Court curtail parliamentary sovereignty? The 
Act does not propose that the Supreme Court be a Canadian style constitutional court but a superior appellate court correcting errors and clarifying and developing the law within the limits of judicial decision-making. ${ }^{1}$ The Justice and Electoral Committee proposed section 3(2) as a response to concerns National and ACT Party members of the Committee held about judicial activism. ${ }^{2}$ What is the basis for this fear of judicial activism as an alleged threat to parliamentary sovereignty? Recent judicial decisions on Treaty of Waitangi issues have drawn critical reaction from Members of Parliament alleging judicial activism. ${ }^{3}$ Some court decisions and academic writing in recent years questioning the ambit and the state of the doctrine of parliamentary sovereignty might also have disturbed some Members of Parliament. ${ }^{4}$ The area of human rights is an area traditionally associated with an activist court. ${ }^{5}$

The idea and fear that courts will use human rights legislation as a gateway for judicial activism is best documented by the discussion prior to the introduction of the Human Rights Act 1998 in the United Kingdom ("Human Rights Act 1998 (UK)"). ${ }^{6}$ There the debate surrounding the Bill's

* Senior Lecturer, Victoria University of Wellington; LLM (VUW); PhD (Goettingen). The author would like to thank Andrew Butler and Susy Frankel for their valuable comments on earlier drafts of this paper and Clara, Conor, and Cillian for their incredible patience.

1 Supreme Court Act 2003, ss 6-14; Supreme Court Bill 2002, no 16-3 (Justice and Electoral Select Committee report commentary, 15 September 2003) 23 ["Supreme Court Bill 2002 Select Committee commentary"].

2 Supreme Court Bill 2002 Select Committee commentary, above n 1, 22-23.

3 Consider for example, Stephen Franks MP's statement in Parliament that Elias CJ should have recused herself from the foreshore and seabed case in the Court of Appeal (Ngati Apa v Attorney-General [2003] 3 NZLR 643) because of her previously shown professional interest in the subject matter and the boldness of the decision: (10 September 2003) NZPD no 36, 8549-8550.

4 See for example, Taylor v NZ Poultry Board [1984] 1 NZLR 394 (CA); Shaw v Commissioner of Inland Revenue [1999] 3 NZLR 154, 158; (1999) 5 HRNZ 217 (CA); Sian Elias "Sovereignty in the 21 $1^{\text {st }}$ Century: Another Spin on the Merry-Go-Around" (2003) 14 PLR 148; Daniel Kalderimis "R v Pora: Debate on Parliamentary Sovereignty" [2001] NZLJ 369; Anthony Bradley "Conflicting Statutory Provisions: the Impact of Fundamental Rights" [2001] NLJ 311.

5 See for example, for fears in regard to judicial activism when the Human Rights Act 1998 (UK) came into force, see, for example, Richard Clayton "The Limits of what's 'Possible': Statutory Construction under the Human Rights Act" [2002] EHRLR 559; James Allan "Moonen and McSense" [2002] NZLJ 142. For an international perspective: Charlotte Parkhill "Dethroning the Sovereign: Human Rights and State Sovereignty" [2002] NZSLJ 67.

6 Brian Mawhinney, Chair of the Conservative Party, argued that the effect of the Bill (which incorporated the European Convention on Human Rights into domestic law and allowed courts to make a declaration of incompatibility against legislation) would be to diminish the sovereignty of Parliament, weaken democracy and fundamentally change the balance of the separation of powers between the executive, the legislature and the judiciary. The result, he said, "will be a further increase in the power of the Executive, the diminution of Parliament and the politicisation of the judiciary": (16 February 1998) 306 GBPD col 793. 
drafting and introduction focused very much on the fear that its enactment would lead to judicial activism. ${ }^{7}$ More than four years later, in numerous speeches, their Lordships in the House of Lords have dealt with the relationship of courts and Parliament and the ambit of the courts' power to interpret legislation. To help the analysis this paper will draw on these decisions where appropriate to contrast the liberal approach of the House of Lords with the approach of the New Zealand Court of Appeal. Such comparison is especially apt since New Zealand and the United Kingdom have similar constitutional frameworks and both made a conscious decision not to enact a supreme bill of rights law. In fact, the Human Rights Act 1998 (UK) is modelled on the relevant sections of the New Zealand Bill of Rights Act 1990 (Bill of Rights Act). ${ }^{8}$ Therefore, the jurisprudence in regard to the Human Rights Act 1998 (UK) provides a good comparative model for New Zealand to test whether New Zealand courts have been truly activist in a manner that threatens parliamentary sovereignty.

The paper will argue that the doctrine of parliamentary sovereignty still stands in New Zealand but that the courts' role has become more overtly that of Parliament's partner in law making. It does not, however, explore and develop from the cases discussed a theory of political-judicial relationship in the area of human rights. This is a specialised matter which will be subject to further research. ${ }^{9}$

This paper will first state briefly what is generally understood by judicial activism and the doctrine of parliamentary sovereignty. Then the assumptions of Parliament when enacting the New Zealand Bill of Rights Act 1990 will be explored. Part IV of the paper will examine New Zealand decisions which have raised the issue of parliamentary sovereignty in regard to statutory interpretation and filling legislative gaps - especially focussing on the doctrine of implied repeal. This analysis will be contrasted with comparable English decisions under the Human Rights Act 1998 (UK) to demonstrate that the New Zealand Court of Appeal has comparatively acted with judicial restraint and caution in respect of parliamentary sovereignty.

7 Clayton, above n 5; Conor A Gearty "Reconciling Parliamentary Democracy and Human Rights" (2002) 118 LQR 248.

8 See Rights Brought Home: The Human Rights Bill (1997) Cmnd 3782, 2.11 ["Rights Brought Home"].

9 Indeed, a first analysis of gathered data seems to suggest that the judgments discussed in this paper, except for Pora, above n 21 and Poumako, above n 46, did not result in parliamentary debate on the issues raised in the decisions. The impact of court decisions upon the policy development and legislative process in Canada has been subject to academic writing in Canada: Grant Huscroft "Protecting Rights and Parliamentary Sovereignty: New Zealand's Experience with a Charter-Inspired, Statutory Bill of Rights" [2002] Windsor Yearbook of Access to Justice 111; Peter Hogg and Alison Bushell "The Charter Dialogue Between Courts and Legislature" (1997) 35 Osgoode Hall LJ 76; Kent Roach The Supreme Court on Trial: Judicial Activism or Democratic Dialogue? (Irwin Law, Toronto, 2001). 


\section{JUDICIAL ACTIVISM}

Judicial activism probably means very different things to different people. Depending on whether or not one agrees with the decision of a court or a judge the term might be used pejoratively or with admiration. The object of this paper is not to discuss whether judicial activism is a good or bad thing but to discuss whether the New Zealand Court of Appeal has been judicially activist. For the purpose of this paper a judge is understood to be delivering judgments displaying judicial activism when: ${ }^{10}$

(a) not applying all and only such relevant, existing, clear, positive law as is available, and (b) making such decisions by drawing on his or her moral, political or religious views a[s] to what the content of the law should be.

A judicially activist judge or court is one with an overt or operative agenda for law reform. In other words, a judge or court that makes well-reasoned policy decisions. The distinction between a judge or court making policy decisions and decisions staying within the realm of interpreting the law as anticipated by Parliament depends on the content of the doctrine of parliamentary sovereignty.

\section{PARLIAMENTARY SOVEREIGNTY}

The content of the doctrine of parliamentary sovereignty is not undisputed. ${ }^{11}$ The definition used for the purpose of this paper is the generally accepted one. Only the facets of the doctrine important for the discussion of this paper will be outlined.

In Rothmans of Pall Mall (NZ) Ltd v Attorney-General Robertson J summarised New Zealand's constitutional position as: ${ }^{12}$

... clear and unambiguous. Parliament is supreme and the function of the Courts is to interpret the law as laid down by Parliament. The Courts do not have a power to consider the validity of properly enacted laws.

10 Tom Campbell "Judicial Activism: Justice or Treason?" (2003) 10 Otago LR 307, 312.

11 See generally for the possible content of parliamentary sovereignty: Philip Joseph Constitutional and Administrative Law in New Zealand (2 ed, Brookers, Wellington, 2001) 461-512 ["Constitutional and Administrative Law in New Zealand"]. For recent discussion about the usefulness of the doctrine, see Elias, above $n 4$.

12 Rothmans of Pall Mall (NZ) Ltd v Attorney-General [1991] 2 NZLR 323, 330 (HC); see also Rights Brought Home, above n 8, 2.13: "In this context, parliamentary sovereignty means that Parliament is competent to make any law on any matter of its choosing and no court may question the validity of any Act that it passes. In enacting legislation, Parliament is making decisions about important matters of public policy. The authority to make those decisions derives from a democratic mandate. Members of Parliament in the House of Commons possess such a mandate because they are elected, accountable and representative." 
The Court of Appeal affirmed this position in Shaw $v C I R^{13}$ stressing that the roles of the legislature, executive, and courts are based on constitutional conventions and that, by convention, the courts' function is to give effect to the intention of Parliament. ${ }^{14}$ Therefore, Parliament's enactments are the ultimate source of law: what Parliament enacts cannot be unlawful. ${ }^{15}$ The question then becomes whether Parliament can legislate to relinquish part of its power. It has been argued that Parliament, since it is omnipotent, cannot give up power in regard to the substance or content of legislation. ${ }^{16}$ The White Paper on a Bill of Rights for New Zealand doubted that the courts would uphold a purportedly entrenched Bill of Rights that was enacted by simple majority in Parliament. ${ }^{17}$ However, Parliament can successfully bind its successors as to the procedures of law making, especially through requiring certain majorities. ${ }^{18}$ The concept of "Parliament as the ultimate source of law" also means that in the areas where Parliament decides to act, courts are generally required to follow the law laid down by Parliament even if this means abandoning in whole or in part principles, doctrines or rules of the common law (that is, judge-made law). From the doctrine of parliamentary sovereignty flows some important principles which give effect to the doctrine. The most important one for the purpose of this paper is the principle of implied repeal which states that Parliament's latest intention prevails over previous ones. ${ }^{19}$

On the other hand it has been acknowledged that parliamentary sovereignty is not without limits. Extra-legal constitutional conventions "bind" Parliament, for example, not to retrospectively reverse judicial decisions, ${ }^{20}$ nor create retrospective offences, ${ }^{21}$ nor impose retrospective penalties. ${ }^{22}$ Another, however controversial, limit to Parliament's law-making power was expressed by Sir Robin Cooke (as he then was) who suggested that the operation of a democratic legislature and the

13 Shaw $v$ CIR, above n 4.

14 Shaw v CIR, above n 4, para 16, judgment of the Court.

15 Compare with Cheney v Conn [1968] 1 All ER 779, 782 (Ch D) Ungoed-Thomas J quoted in Haliburton v Broadcasting Commission (3 December 1998) HC AK CP342/98, 8 Morris J.

16 Constitutional and Administrative Law in New Zealand, above n 10, 540.

17 "A Bill of Rights for New Zealand: A White Paper" [1985] AJHR A 657 ["White Paper"].

18 Constitutional and Administrative Law in New Zealand, above n 10, 513 and following.

19 Constitutional and Administrative Law in New Zealand, above n 10, 483; Interpretation Act 1999, s 7.

20 See Clutha Development (Clyde Dam) Empowering Act 1982. The Act was passed to reverse a Planing Tribunal decision.

21 New Zealand Bill of Rights Act 1990, s 26.

22 Compare $R$ v Pora [2001] 2 NZLR 37; (2000) 6 HRNZ 129 (CA) - see discussion of this case under Part V B 2 (a) New Zealand cases on implied repeal; see also New Zealand Bill of Rights Act 1990, s 26; Criminal Justice Act 1985; Sentencing Act 2002, s 6. 
operation of independent courts should be seen as the two pillars of a free and democratic society. ${ }^{23}$ He said that: ${ }^{24}$

[I]f a change, by legislation or otherwise, were seen to undermine either of them to a significant extent, it would be the responsibility of the Judges to say so and, if their judgments to that effect were disregarded, to resign or to acknowledge frankly that they are prepared to depart from their judicial oath and to serve a state not entitled to be called a free democracy.

However, he noted that his statements were "certainly not intended as an incitement to judicial activism." 25 Have the New Zealand courts and in particular the Court of Appeal taken Lord Cooke's statements too far after the implementation of the New Zealand Bill of Rights Act 1990? Has the Court of Appeal challenged the law-making power of Parliament using the New Zealand Bill of Rights Act 1990 or human rights in general?

\section{ASSUMPTIONS BEHIND THE BILL OF RIGHTS ACT}

In addressing the questions posed above, a useful starting-point is an examination of Parliament's intent in enacting the Bill of Rights Act to ascertain whether Parliament anticipated some judicial activism.

In 1985 the Labour Government published a White Paper, entitled "A Bill of Rights for New Zealand". ${ }^{26}$ The White Paper proposed not only the incorporation of most of the human rights stated in the International Covenant on Civil and Political Rights but also the enactment of these rights in a supreme law bill of rights. ${ }^{27}$ However, public opinion was against the proposition of an entrenched bill of rights. The Justice and Law Reform Select Committee cited the power proposed to be given to the judiciary as the principal reason for the opposition. ${ }^{28}$ Many people were unhappy at the prospect of redistributing power from elected representatives who were directly accountable and giving it to an appointed judiciary. ${ }^{29}$

The Committee, nonetheless, recommended the introduction of a bill of rights as an ordinary statute. It thought that such a measure would have some moral value and could educate New Zealanders about human rights issues (the lack of understanding about fundamental human rights

23 Robin Cooke "Fundamentals" [1988] NZLJ 158, 164.

Cooke, above n 22, 164.

Cooke, above n 22, 164.

White Paper, above n 16.

White Paper, above n 16, 21-23.

28 Justice and Law Reform Committee "Final Report of the Justice and Law Reform Committee on a White Paper on a Bill of Rights for New Zealand" [1987-1990] AJHR I 8C 2-3.

29 Justice and Law Reform Committee, above n 27, 2-3. 
among the New Zealand public was of great concern to the Committee). The Committee also considered that a bill of rights could provide valuable checks on the actions of the executive. ${ }^{30}$ When, finally, the New Zealand Bill of Rights Bill was introduced into Parliament in 1989, the Prime Minister, the Rt Hon Geoffrey Palmer pointed out that the proposed bill would encapsulate the role of Parliament as guardian of fundamental rights and freedoms of New Zealand. The New Zealand Bill of Rights Act 1990 would, therefore, become a "parliamentary Bill of Rights".31 To make the task of guarding the fundamental rights of New Zealanders a responsibility of Parliament was to state that enacting the New Zealand Bill of Rights would not break with the doctrine of parliamentary sovereignty. ${ }^{32}$ Indeed, section 4 of the Bill of Rights Act explicitly states that it is outside the power of the courts to repeal, revoke or hold invalid or ineffective any enactment, or to decline to apply any provision because the court considers the enactment or any provision of an enactment is inconsistent with the Bill of Rights Act. Section 6 reflects the view that the Act is a parliamentary Bill of Rights Act by directing that the courts interpret an enactment in the manner most consistent with the rights and freedoms contained in the Bill of Rights Act.

As the Select Committee found, the New Zealand public saw (and probably still sees) Parliament as the primary means for addressing rights issues. Parliament is not seen as a threat to fundamental rights, especially civil liberties, but, on the contrary, is seen as securing rights by responsible government. On this view, parliamentary supremacy and the rule of law are essential for the protection of human rights. ${ }^{33}$

Similarly, the government of the United Kingdom reached the conclusion that courts should not have the power to set aside primary legislation, past or future, on the ground of incompatibility with the European Convention on Human Rights since the government attached great importance to parliamentary sovereignty. The government was of the view that to make provision in the Human Rights Act for the courts to set aside Acts of Parliament would have conferred on the judiciary a general power over the decisions of Parliament, which courts do not possess under current

30 Justice and Law Reform Committee, above n 27, 2-3.

31 Rt Hon Sir Geoffrey Palmer "New Zealand Bill of Rights Bill: Introduction" (10 October 1989) 502 NZPD 13038.

32 The doctrine of parliamentary sovereignty is understood to mean: "A sovereign Parliament is omnicompetent and may legislate without restriction on any subject-matter. A sovereign Parliament is not impeded by any federal division of powers or entrenched bill of rights": Constitutional and Administrative Law in New Zealand, above n 10, 16 para 1.3.15.

33 See Rt Hon Sir Geoffrey Palmer "New Zealand Bill of Rights Bill: Third Reading" (21 August 1990) 510 NZPD 3760. Compare for Australia: Haig Patapan "Competing Visions of Liberalism: Theoretical Underpinnings of the Bill of Rights Debate in Australia" (1997) 21 Melb U LR 497, 501. 
constitutional arrangements, and would be likely on occasion to draw the judiciary into serious conflict with Parliament. ${ }^{34}$

\section{THE COURTS' DECISIONS}

Analysis of two issues can help to get a measure of the Court of Appeal's understanding of the doctrine of parliamentary sovereignty over the last twelve years. First, has the New Zealand Court of Appeal thought it had the mandate under the Bill of Rights Act to fill gaps left in legislation? Second, how has the Court interpreted statutes, including the relationship between earlier and later legislation, in light of the enactment of the Bill of Rights Act? Selected New Zealand Court of Appeal decisions will be contrasted with selected decisions by the House of Lords under the Human Rights Act 1998 (UK) to assess how "activist" the Court of Appeal has been.

\section{A The New Zealand Court of Appeal - Filling Gaps in the Legislation}

One of the most apparent gaps is in the Bill of Rights Act itself: it did not provide for any remedies should the court find an infringement of the Bill of Rights Act. Very early in Bill of Rights jurisprudence, the Court of Appeal found that it had the mandate to develop remedies such as the inadmissibility of evidence and stay of proceedings where infringements are found to have occurred. ${ }^{35}$ While some commentators criticised these developments, ${ }^{36}$ to the extent that remedies of these types were available pre-Bill of Rights, the extension post-Bill of Rights can be regarded as interstitial rather than radical.

The first big leap of "judicial activism" probably could be seen when the Court of Appeal created a public law compensatory remedy in the case of Simpson v Attorney-General (Baigent's case). ${ }^{37}$ In this case the Court not only created ${ }^{38}$ a new remedy but also did a balancing act of statutory interpretation.

One of the problems faced by plaintiffs (and ultimately the Court) in Baigent's case was the statutory immunities which could be found in legislation barring damages awards against the Crown and police officers. This was particularly problematic because the police officers who searched the

34 Rights Brought Home, above n 8, 2.13.

35 See for example, Ministry of Transport v Noort [1992] 3 NZLR 260 (CA); Martin v Tauranga District Court [1995] 2 NZLR 419 (CA); see pre-Bill of Rights in regard to exclusion of evidence: $R v$ Kirifi [1992] 2 NZLR 8, 12 (CA) Cooke P.

36 John Smillie "'Fundamental Rights', Parliamentary Supremacy and the New Zealand Court of Appeal" (1995) 111 LQR 209.

37 Simpson v Attorney-General (Baigent's case) [1994] 3 NZLR 667; (1994) 1 HRNZ 42 (CA) ["Baigent's case"].

38 For an explicit acknowledgement that the Court of Appeal was engaged in creation see Attorney-General $v$ PF Sugrue [2004] 1 NZLR 207 para 69; (2003) 7 HRNZ 137, para 70 (CA) Blanchard J. 
Baigent house did so with a warrant issued on incorrect factual assumptions and continued the search despite the knowledge that they were searching the wrong premises. It would have been open to the Court to state that Parliament's intention in light of section 6(5) of the Crown Proceedings Act 1950, section 39 of the Police Act 1958, and section 26(3) and section 27 of the Crimes Act 1961 was that the Crown and individual police officers were immune against civil proceedings if the police acted in good faith on a warrant or according to a process issued by judicial authority. As to any action under the Bill of Rights Act, an additional argument for the view that Parliament did not intend to allow the Crown to be held liable in such situations was that the draft Bill in the White Paper had provided for a remedies clause, but this was not proceeded with in the 1990 Act. $^{39}$ This argument received support in the dissenting judgment of Gault J. In his judgment his Honour found that the existing law provided effective remedies for persons whose rights and freedoms were infringed or denied and that the immunity provisions should be given effect to (although he would have given them a narrower effect than the majority). ${ }^{40}$

However, the majority of the Court took another approach. It held that the immunities provided for did not apply in an action based on the Bill of Rights Act since this was an action in public law and not in tort at which the immunities were aimed. ${ }^{41}$ Also, the Court did not find itself deterred from creating a new public law remedy. As Casey J put it: ${ }^{42}$

I do not regard the absence of a remedies provision in the Act as an impediment to the Court's ability to 'develop the possibilities of judicial remedy' as envisaged in art 2(3)(b) [of the International Covenant on Civil and Political Rights].

Casey J also pointed out that it would be strange that Parliament must be taken as contemplating that New Zealand citizens could go to the United Nations Human Rights Committee under the Optional Protocol to the International Covenant on Civil and Political Rights but could not obtain redress against human rights abuses under the domestic law implementing the Covenant - the Bill of Rights Act. ${ }^{43}$

39 See argument for the Crown as reported in Baigent's case, above n 36, NZLR 676; HRNZ 57 Cooke P. The draft Bill, clause 25 read "Anyone whose rights or freedoms as guaranteed by this Bill of Rights have been infringed or denied may apply to a court of competent jurisdiction to obtain such remedy as the court considers appropriate and just in the circumstances."

40 Baigent's case, above n 36, NZLR 711, 714; HRNZ 96, 100 Gault J.

41 Baigent's case, above n 36, NZLR 677, HRNZ 58 Cooke P; NZLR 691-692, HRNZ 74-75 Casey J; NZLR 696, 699-701, HRNZ 80, 83-85 Hardie Boys J.

42 Baigent's case, above n 36, NZLR 691, HRNZ 73. See also Baigent's case, above n 36, NZLR 676, HRNZ 57 Cooke $\mathrm{P}$.

43 Baigent's case, above n 36, NZLR 691, HRNZ 74. 
Hardie Boys J summarised the Court's view of Parliament's intent in enacting the Bill of Rights Act as follows: ${ }^{44}$

The New Zealand Bill of Rights Act, unless it is to be no more than an empty statement, is a commitment by the Crown that those who in the three branches of the Government exercise its functions, powers, and duties will observe the rights that the Bill affirms. It is I consider implicit in that commitment, indeed essential to its worth, that the Courts are not only to observe the Bill in the discharge of their own duties but are able to grant no reason to think that this should depend on the terms of a written constitution.

Baigent's case prompted the question of whether the subject of remedies under the Bill of Rights Act should be left to be further developed judicially, or whether legislative clarification or reform might be desirable. Accordingly, the government asked the New Zealand Law Commission to consider Baigent's case. The Law Commission endorsed the approach taken by the Court of Appeal, and concluded that no legislation should be introduced to remove the general remedy for breach of Bill of Rights Act established by this case. ${ }^{45}$

Post-Baigent the Court of Appeal has gone even further. In an obiter dictum in Moonen $v$ Film and Literature Board of Review (Moonen) the Court stated that it could issue a declaration of incompatibility where it found that a statutory provision constituted an unreasonable limitation on a right "guaranteed" in the Bill of Rights Act, and where that limitation could not be demonstrably justified in a free and democratic society. The Court thought this valuable if the matter came to be examined by the United Nations Human Rights Committee or in case the issue arose in Parliament. ${ }^{46}$ A more detailed analysis as to why such a declaration of incompatibility would not infringe parliamentary sovereignty followed one year later.

In his dissenting judgment in $R v$ Poumako, Thomas $\mathrm{J}$ would have issued a formal declaration of incompatibility in regard to section 2(4) of the Criminal Justice Amendment Act 1999. He held that section to be inconsistent with section 25(g) of the Bill of Rights Act and article 15(1) of the International Covenant on Civil and Political Rights. ${ }^{47}$ His Honour stated six reasons why a declaration of incompatibility was a valid remedy under the Bill of Rights. First he argued that a

44 Baigent's case, above n 36, NZLR 702, HRNZ 86.

45 New Zealand Law Commission Crown Liability and Judicial Immunity: A Response to Baigent's Case and Harvey v Derrick (NZLC R37, Wellington, 1997) 26-29.

46 Moonen v Film and Literature Board of Review [2000] 2 NZLR 9, para 20; (1999) 5 HRNZ 224, para 20 (CA); Parliament took up the idea of the courts issuing declarations of incompatibility in section 92I of the Human Rights 1993 (as amended in 2001) in regard to section 19 of the New Zealand Bill of Rights Act 1990.

$47 \quad R$ v Poumako [2000] 2 NZLR 695, 719; (2000) 5 HRNZ, 652, 683 (CA). 
declaration is in line with the purpose of the Act as stated in its Long Title. ${ }^{48}$ Furthermore, section 6 of the Bill of Rights Act directed the courts to give priority to human rights whenever possible, "thus recognising that the Courts are necessarily the guardians of the norms underlying those rights". ${ }^{49}$ To fulfil its function the Court needed to be able to declare legislation incompatible with the Bill of Rights Act. Thirdly, a declaration could also be seen as supplementing the reporting process as stipulated in section 7 of the Bill of Rights Act since amendments to legislation did not fall under the reporting process. Further, to give section 5 a meaningful role within the framework proposed by the Bill of Rights Act, courts must be able to declare legislation incompatible. Thomas $\mathrm{J}$ also pointed out that since Parliament and the courts share the same commitment to fundamental human rights, Parliament would want an indication from the courts as to whether legislation was human rights compliant. Finally, by making a declaration the Court did not infringe the doctrine of parliamentary sovereignty since a declaration does not invalidate the statute nor does it mean that Parliament cannot pass legislation to overrule the courts. Only a judiciary which impartially and "fearlessly" exercises its function can fulfil its constitutional function. ${ }^{50}$

Even though the Court's decisions in Baigent's case and Moonen were heavily criticised ${ }^{51}$ and could be seen as examples of judicial activism, Parliament certainly did not object. Parliament has acted on the Law Commission's advice and has not enacted any legislation curtailing Baigent damages, leaving it to the courts to develop public law compensation further. ${ }^{52}$ Next, the Court's idea of issuing declarations of inconsistency was taken up by Parliament when amending the Human Rights Act 1993. Since the Human Rights Amendment Act 2001 came into force, the Human Rights Review Tribunal and, on appeal, courts can issue declarations of inconsistency in regard to section

48 New Zealand Bill of Rights Act 1990, long title: "An Act - (a) To affirm, protect, and promote human rights and fundamental freedoms in New Zealand; and (b) To affirm New Zealand's commitment to the International Covenant on Civil and Political Rights".

$49 R v$ Poumako, above n 46, NZLR 717, HRNZ 679 Thomas J.

$50 \quad R v$ Poumako, above n 46, paras 94-103 Thomas J.

51 Smillie, above n 35; James Allan "Speaking with the Tongues of Angels: The Bill of Rights, Simpson and the Court of Appeal" [1994] BRB 2.

52 See in regard to the latest developments: Attorney-General v PF Sugrue, above n 37; Wilding v AttorneyGeneral [2003] 3 NZLR 787; (2003) 7 HRNZ 158 (CA). In Attorney-General v PF Sugrue, the Court of Appeal decided that the Limitation Act 1950, s 4(1)(d) was not applicable to Baigent-type compensation. However, the Court went on to hold that despite the fact that the Limitation Act 1950 was not applicable that would not mean that claims for Baigent damages could be made indefinitely. The Court compared Baigent damages with equitable compensation. "And, as with equitable awards, the Court should be able to refuse monetary relief if the plaintiff delays too long ... ." (Attorney-General v PF Sugrue, above n 37, paras 69-70 Blanchard J). The case of Wilding $v$ Attorney-General concerned the question whether Baigent damages were barred by the accident compensation legislation. The Court held that in a case of a claim based on personal injury, Parliament had made the decision that the effective remedy should be found in the accident compensation legislation (Wilding v Attorney-General [2003] 3 NZLR 787; (2003) 7 HRNZ 158, paras 13-16 Blanchard J). 
19 of the Bill of Rights Act (the section concerning discrimination). ${ }^{53}$ Therefore, it can be said that the Court of Appeal provided some guidance for Parliament on how to sensibly extend legislation in the spirit of the parliamentary debates and New Zealand's international obligations, advice which Parliament has, it seems, willingly accepted.

Parliament is also no stranger to being advised by specialists outside Parliament on legislative issues. Sections 6(1)(a) and 8 of the Treaty of Waitangi Act 1975 confer the task on the Waitangi Tribunal of, inter alia, examining any enacted legislation (section 6(1)(a)) or proposed legislation (section 8) for consistency with the principles of the Treaty of Waitangi. Even though the Waitangi Tribunal is not a court it hears evidence and investigates claims made under the Act. It issues recommendations and the Minister of Maori Affairs has to table in Parliament an annual report in which the progress made in regard to the recommendations is laid out. Under section 4(2)(a) at least one member of the Tribunal has to be a judge. ${ }^{54}$ Whereas in the Treaty area Parliament does not seem to feel that its sovereignty has been intruded upon by advice from an outside quasi-judicial body it is interesting to note, in contrast, that in the human rights area a similar approach is missing. In fact one of the tasks of the Human Rights Commission has been to comment on the consistency of legislation with human rights standards but, apart from the incomplete Consistency 2000 report which focussed on discrimination only, the Commission has never played a prominent role in that regard. ${ }^{55}$ Nor does the Human Rights Commission have the same quasi-judicial status as the Waitangi Tribunal. The work of the Waitangi Tribunal shows that it can be valuable to get advice from a body which deals with claims rather than only with abstract issues. In regard to human rights the need for independent external advice has been met by the Court of Appeal.

The question becomes not whether the Court could create these remedies (since courts have created causes of action and remedies throughout history) ${ }^{56}$ but whether it is legitimate for the Court to seize the initiative to create the remedies, bearing in mind the history of the Bill of Rights Act. Philip Joseph in a recent conference paper sees the political and judicial branches as equally committed to the business of government. He argues that although tensions may arise between them,

53 Human Rights Act 1993, s 92J. According to section 92K of the Act, the Minister responsible for the legislation has to bring the declaration to the attention of Parliament and has to bring before Parliament a response regarding the declaration.

54 Either a judge or retired judge of the High Court or the Chief Judge of the Maori Land Court.

55 The Human Rights Commission has the power to inquire generally into any matter, including any enactment or law, if it appears to the Commission that the matter involves, or may involve, the infringement of human rights: Human Rights Act 1993, s 5(2)(h). The Commission also has the power to report to the Prime Minister on the implications of any proposed legislation that it considers may affect human rights: Human Rights Act 1993, s 5(2)(k)(iii).

56 For example, Donoghue v Stevenson [1932] AC 562 (HL), Mareva injunctions or Anton Piller orders. 
neither should seek to supplant the other. ${ }^{57}$ The way the New Zealand Court of Appeal has filled the gap in regard to remedies in the Bill of Rights Act is an example of how both branches can coexist. It is not an example of judicial activism. The Court of Appeal has not intruded on parliamentary sovereignty; instead it has complemented Parliament and has offered practical solutions to problems Parliament might have overlooked when enacting legislation or deliberately left open since it felt that the arm of government which had more practical experience with the matter was better suited to dealing with it. In regard to remedies, the Court has carefully extended existing common law remedies relating to the exclusion of evidence ${ }^{58}$ and stay of proceedings. ${ }^{59}$ Further, as regards Baigent compensation, not only were damages known under the Human Rights Commission Act 1977 and the Race Relations Act 1971 for the breach of non-discrimination rights $^{60}$ but Baigent-style public law damages were also known in other jurisdictions. ${ }^{61}$ And in regard to declarations of inconsistencies not only, as Thomas J pointed out in his judgment, are they the logical extension of section 5 of the Bill of Rights Act but the Court also had the advantage of section 4 of the Human Rights Act 1998 (UK) ${ }^{62}$ as a model - an Act closely modelled on the New Zealand Bill of Rights Act. The Court was "activist" in seizing opportunities to create remedies; however, the Court was careful with what it did with its opportunity. The Court did not create anything adventurously new. It applied ideas which had been around and tested before. As Philip Joseph pointed out, by doing that it can be said that the Court of Appeal was merely asserting "the final authority simply by virtue of the judicial function"63 and, therefore did not need to shy away from taking the opportunities.

57 Philip Joseph "Parliament, the Courts and the Collaborative Enterprise" (Society of Legal Scholars Annual Conference, Oxford, September 2003) 1-2, 11 and following ["Parliament, the Courts and the Collaborative Enterprise"].

58 For example, $R$ v Shaheed [2002] 2 NZLR 377; (2002) 6 HRNZ 561 (CA).

$59 \quad R \vee B$ (reasons for decision) (1995) 1 HRNZ 521.

60 Human Rights Commission Act 1977, ss 38, 40, 42; Race Relations Act 1971, ss 17, 21 , 22.

61 Cases mentioned in the judgment are, for example: Maharaj $v$ Attorney-General of Trinidad and Tobago (No 2) [1979] AC 385; Nilabati Behera v State of Orissa (1993) Crim LJ 2899; The State (At the Prosecution of Quinn) v Ryan [1965] IR 70, 122.

62 Human Rights Act 1998 (UK), s 4:

(1) Subsection (2) applies in any proceedings in which a court determines whether a provision of primary legislation is compatible with a Convention right.

(2) If the court is satisfied that the provision is incompatible with a Convention right, it may make a declaration of that incompatibility.

63 "Parliament, the Courts and the Collaborative Enterprise", above n 56, 10. 


\section{B Statutory Interpretation}

Section 6 of the Bill of Rights Act and section 3 of the Human Rights Act 1998 (UK) require the court to give an enactment a meaning which is consistent with the Bill of Rights Act or Human Rights Act respectively wherever possible. The question arises whether the courts have used their power of Bill of Rights Act or UK Human Rights Act consistent interpretation to rewrite legislation through the back door.

\section{Interpretation of words and phrases}

(a) New Zealand cases

In Quilter v Attorney-General ${ }^{64}$ (Quilter) the Court of Appeal had to decide the question whether the Marriage Act 1955 could be interpreted to embrace same-sex couples. The Court was very clear that it could not rewrite the law contrary to Parliament's wish. To interpret the Marriage Act 1955 to include same-sex couples would be to assume the role of the lawmaker. ${ }^{65}$ Section 4 of the Bill of Rights Act says that Parliament has reserved to itself all legislative functions. ${ }^{66}$ Tipping J pointed out that, on its enactment, the Marriage Act 1955 was clear beyond doubt in the meaning which it attributed to the concept of marriage. Legislation passed after the enactment of the Bill of Rights Act supports that initial meaning. Therefore, there is no basis upon which the Marriage Act 1955 can (in terms of section 6) be interpreted as permitting same-sex marriage:67

In addition to those points, it is highly unlikely that Parliament would have intended to make such a substantial change to one of society's fundamental institutions by the indirect route of [section] 19 and [section] 6 of the Bill of Rights [Act].

The Quilter case would have been an excellent chance for the Court of Appeal to show real "judicial activism". Countries like Denmark had already legalised same-sex marriages and a considerable amount of academic writing existed suggesting that same-sex couples should be able to legalise their relationship. ${ }^{68}$ The Court could have given the Marriage Act 1955 a 1997

64 Quilter v Attorney-General [1998] 1 NZLR 523; (1997) 4 HRNZ 170 (CA).

65 Quilter v Attorney-General, above n 63, NZLR 526-527, HRNZ 178 Gault J; NZLR 572-573, HRNZ 223 Tipping J.

66 Quilter v Attorney-General, above n 63, NZLR 572-573, HRNZ 223 Tipping J.

67 Quilter v Attorney-General, above n 63, NZLR 581, HRNZ 232 Tipping J. See also Quilter v AttorneyGeneral, above n 63, NZLR 555, HRNZ 206 Keith J.

68 Danish Registered Partnership Act 1989; Registered Partnership Act 1996 (Iceland); Swedish and Norwegian Registered Partnership Acts 1994; James Trosino "American Wedding: Same-Sex Marriage and the Miscegenation Analogy" (1993) 73 BU L Rev 93. It also should be noted that recent Canadian decisions about same-sex marriages have all found in favour of same-sex marriages: Halpern $v$ Canada (AttorneyGeneral) (2002) 215 DLR $\left(4^{\text {th }}\right) 223$ affirmed by Court of Appeal: Paul Rishworth "Human Rights" [2003] NZ Law Rev 261, 271; Barbeau v Attorney-General (British Columbia) [2003] BCCA 251 (CA); Hendricks 
reinterpretation arguing that Parliament's intent as shown by section 6 of the Bill of Rights Act in 1990 meant that the word "marriage" in the Act should include same-sex couples. Tipping J acknowledged in his judgment that the Marriage Act 1955 used gender-neutral language throughout the Act and that "marriage" was not defined in the Act. His Honour used section 15 in the Second Schedule to the Act and the time of the enactment to deduce Parliament's intent. ${ }^{69}$ The wording in the Second Schedule would not have prevented the Court from finding that the Act covered samesex couples. And the Court could have overcome Parliament's 1955 intention by emphasising Parliament's 1990 intention, shown when enacting section 6 of the Bill of Rights Act, that legislation should be read in a Bill of Rights Act compliant way. However, the Court felt that this was a decision for Parliament; in so holding it placed great emphasis on the limits of judicial decisionmaking.

Two years after Quilter, the Court of Appeal was asked to interpret a provision in another sensitive area. The correct interpretation and application of the words "promotes or supports" in section 3(2) of the Films, Videos, and Publications Classification Act 1993 was the issue in Moonen $v$ Film and Literature Board of Review. ${ }^{70}$ The Court held that in considering the correct meaning of those words a Bill of Rights Act consistent approach was required. ${ }^{71}$ The application of sections 5 and 6 of the Bill of Rights Act meant that the interpretation of the words "promotes or supports" should impinge as little as possible on freedom of expression. The Court held that the concepts of "promotion" and "support" are concerned with "the effect of the publication, not with the purpose or the intent of the person who creates or possesses it."72

In Moonen, the Court of Appeal had more scope than the Court in Quilter since the legislative history of the phrase in question had not been documented. The Court endeavoured to find a definition which least infringed freedom of expression and shifted the definition from a subjective to an objective test. It is now only important what effect the publication has; not what the author actually wanted to express. The subsequent inquiry of the Government Administration Committee into the Operation of the Films, Videos, and Publications Classification Act 1993 and related issues,

v Quebec (Attorney-General) [2002] JQ 3816 (Superior Court of Quebec) as has the Massachusetts Supreme Court: CNN.com "Gay Marriage Decision Penned by Anti-Apartheid Veteran" <Hhttp://www.cnn.com/2003/LAW/11/24/gay.marriage.chief.justice.ap/index.htmlH> (last accessed 21 May 2004).

69 Quilter v Attorney-General, above n 63, NZLR 577-578, HRNZ 228 Tipping J.

70 Moonen v Film and Literature Board of Review, above n 45.

71 Moonen v Film and Literature Board of Review, above n 45, para 27.

72 Moonen v Film and Literature Board of Review above n 45, para 29. Neither in the Report of the Internal Affairs and Local Government Committee on the Films, Videos and Publications Classification Bill: [1993] XXIII AJHR I 7A nor in its third reading is the meaning of "promotes and supports" discussed. 
found that the Court of Appeal's interpretation of "promotes and supports" adequately carried out the intent of Parliament in that it took account of section 14 of the Bill of Rights Act. ${ }^{73}$

\section{(b) English cases}

After three years of operation, section 3 of the Human Rights Act 1998 (UK) has been invoked in a considerable number of decisions. One of the leading cases in regard to the rights interpretation of United Kingdom legislation is $R v A$ (No 2). ${ }^{74}$ This case concerned a section in the Youth Justice and Criminal Evidence Act which severely restricted cross-examination of a rape complainant about the kind of sexual conduct which could have been relevant to a defence alleging consent. Parliament enacted the relevant section in 1999 to ensure that women who complained about being raped were treated with dignity in court and given protection against cross-examination and evidence that unnecessarily invaded their privacy. It was the intention of the legislation, as stated in Parliament, to keep as much evidence of complainants' previous sexual behaviour out of trials as possible. ${ }^{75}$ The House of Lords unanimously held that the section had to be read subject to section 3 of the Human Rights Act 1998 (UK). Lord Steyn in the leading speech stated that section 3 required the Court to find an interpretation compatible with Convention rights (if at all possible). His Lordship quoted the Lord Chancellor who observed during the progress of the Human Rights Bill through Parliament that "in 99 per cent of the cases that will arise, there will be no need for judicial declarations of incompatibility" and quoted the Home Secretary as stating, "[w]e expect that, in almost all cases, the courts will be able to interpret the legislation compatibility with the Convention."76 Lord Steyn concluded from these statements that "[i]n accordance with the will of Parliament as reflected in section 3 it will sometimes be necessary to adopt an interpretation which linguistically may appear strained." ${ }^{77}$ For his Lordship that meant that the section in question could be read as: ${ }^{78}$

[S]ubject to the implied provision that evidence or questioning which is required to ensure a fair trial under article 6 of the Convention should not be treated as inadmissible. The result of such reading would be that sometimes logically relevant sexual experiences between a complainant and an accused may be admitted ... On the other hand, there will be cases where previous sexual experiences between a complainant and an accused will be irrelevant ... Where the line is to be drawn must be left to the judgment of trial judges.

73 Government Administration Committee "Inquiry into the Operation of the Films, Videos, and Publications Classification Act 1993 and Related Issues" (Wellington, March 2003) 25-27. 
In contrast, Lord Hope stated that section 3 was just a rule of interpretation and did not entitle judges to act as legislators. ${ }^{79}$ His Lordship found that it would contradict the clear intention of Parliament to read in a provision which would enable the court to exercise a wider discretion than that permitted by the section in question. ${ }^{80}$ He noted "in passing" that before the second reading of the Bill the responsible Minister made a statement that its provisions were compatible with the Human Rights Act $1998 .{ }^{81}$ His Lordship did not attach a lot of weight to that fact since they were merely expressions of opinion by the Minister and were not binding on the court. The statement could be seen as part of the legislative history, indicating Parliament's intention to adhere to European Convention rights. ${ }^{82}$ Lord Hope reached the same result as Lord Steyn by reading down parts of the section in question. Similarly, in $R v$ Offen the Court of Appeal interpreted section 2 of the Criminal (Sentences) Act to take a broad view of the meaning of "exceptional circumstances" in making the power to impose a life sentence following a conviction for a second serious offence compatible with the prohibition of inhuman and degrading treatment. ${ }^{83}$

The other leading case in regard to the interpretation of statutes has been $R v$ Lambert. $^{84}$ Lambert was charged with possession of a class A controlled drug with intent to supply. His defence was that although he had been found in possession of a bag containing the drug he had neither known nor suspected nor had reason to suspect the nature of the contents of the bag. After his conviction he appealed on the ground that he should not have been required to establish his defence on the balance of probabilities since such a requirement conflicted with the presumption of innocence guaranteed by article 6(2) of the Convention for the Protection of Human Rights and Fundamental Freedoms, as incorporated by the Human Rights Act 1998. In this case the House of Lords held that section 3 of the Human Rights Act required that the reverse onus provision in the Misuse of Drugs Act be read as merely imposing an evidential burden on the defendant not a legal burden as had been previously understood to be the case. ${ }^{85}$ Interestingly, $R v$ Lambert can be contrasted with the decision of the New Zealand Court of Appeal in $R v$ Phillips. ${ }^{86}$ In that case the Court of Appeal also had to consider the issue of a reverse onus provision in respect of the offence of possession for sale in the New Zealand Misuse of Drugs Act 1975. The Court held that section 6 of the Bill of Rights Act had no application unless the enactment in question could be given a

\footnotetext{
$79 R \vee A$ (No 2), above $n$ 73, para 108 Lord Hope.

$80 R v A$ (No 2), above n 73, para 109 Lord Hope.

$81 R \vee A$ (No 2), above n 73, para 69 Lord Hope.

$82 R \vee A$ (No 2), above n 73, para 69 Lord Hope.

$83 R v$ Offen [2001] 1 WLR 421 (CA).

$84 R v$ Lambert [2002] 2 AC 545 (HL).

$85 R v$ Lambert, above n 83, 574 para 42.

$86 R v$ Phillips [1991] 3 NZLR 175 (CA).
} 
meaning consistent with the rights and freedoms contained in the Bill of Rights Act. The expression "until the contrary is proved" in the relevant section could not be taken to mean "unless sufficient evidence is given to the contrary". ${ }^{87}$ This was the opposite conclusion to that reached in $R v$ Lambert.

\section{(c) Comparison}

Section 3 of the Human Rights Act 1998 (UK) has been used more adventurously in decisions such as $R \vee A$ (No 2) and $R v$ Offen than section 6 of the Bill of Rights Act when it comes to the interpretation of statutory provisions. ${ }^{88}$ In particular it is interesting to note the cautious approach taken by the New Zealand Court of Appeal in $R v$ Phillips compared to the more adventurous approach taken by the House of Lords in $R v$ Lambert.

From the decisions discussed it would not be far-fetched to think that the House of Lords would have come to a different result in a case like Quilter, especially given the Canadian jurisprudence and the acknowledgement of same-sex marriages in Europe, for example in Denmark and Germany. However, that has not occurred; quite the opposite. In Bellinger $v$ Bellinger ${ }^{89}$ their Lordships had to decide whether the inability of a post-operative "male to female" transsexual to marry a male violated the right to a family and privacy in article 8 of the European Convention on Human Rights. The Matrimonial Causes Act 1973 holds a marriage void unless the parties are respectively "male and female". 90 The question for the House of Lords was whether or when a born male person could become female and, therefore, marry a male person. In regard to the difficult question of gender reassignment the Court held that this issue was not for the courts to decide, since a coherent policy about gender reassignment needed to be developed across all relevant fields of law. In the context of gender reassignment the Court also considered whether it should be possible for persons of the same-sex to marry since it was argued to be one way to resolve problems such as those confronting Mrs Bellinger. The House of Lords, however, found that this issue would involve a fundamental change in the traditional concept of marriage which raised a question that ought to be considered as part of an overall review of the most appropriate way to deal with the difficulties confronting transsexual people. ${ }^{91}$ In addition, the House of Lords made a declaration that the section 11(c) of

$87 \quad R v$ Phillips, above n 85, 176-177.

88 See critical discussion in regard to $R v A$ (No 2), above $\mathrm{n} 73$ and $R v$ Offen, above $\mathrm{n} 82$ in Gavin Phillipson "(Mis)Reading Section 3 of the Human Rights Act" (2003) 119 LQR 183, 188: pointing out that one explanation for the two decisions might be that the House of Lords wanted to protect judges' own sphere of discretion in regard to the admissibility of evidence and sentencing.

91 Bellinger v Bellinger, above n 88, para 47-48 Lord Nicholls. 
the Matrimonial Causes Act 1973 was incompatible with article 8 of the European Convention on Human Rights. ${ }^{92}$

A further example of the House of Lords' awareness of the limits to its role of interpreting legislation rather than legislating can be seen in Re S (Care Order: Implementation of Care Plan) ${ }^{93}$ where the House of Lords had to examine the Court of Appeal's interpretation of the Children Act. First, the Court of Appeal enunciated guidelines intended to give trial judges a wider discretion to make an interim care order, rather than a final care order. The second innovation concerning the position after the Court has made a final order was more radical. The Court of Appeal propounded a new procedure, by which, at the trial, the essential milestones of a care plan would be identified and elevated to a "starred status". If a starred milestone was not achieved within a reasonable time after the date set at trial, the local authority was obliged to "reactivate the interdisciplinary process that contributed to the creation of the care plan". ${ }^{94}$ At the least the local authority had to inform the child's guardian of the position. Either the guardian or the local authority would then have the right to apply to the court for further directions. ${ }^{95}$ Lord Nicholls therefore asked whether the courts had the power to introduce into the working of the Children Act a range of rights and liabilities not sanctioned by Parliament. ${ }^{96}$ He observed that in applying section 3, courts must be mindful that the Human Rights Act reserved the amendment of primary legislation to Parliament. His Lordship held: ${ }^{97}$

By this means the Act seeks to preserve parliamentary sovereignty. The Act maintains the constitutional boundary. Interpretation of statutes is a matter for the courts; the enactment of statutes, and the amendment of statutes, are matters for Parliament.

Lord Nicholls acknowledged the problem that what for one person is robust and sensible interpretation might be for another person impermissibly creative. However, his Lordship stated that "a meaning which departs substantially from a fundamental feature of an Act of Parliament is likely to have crossed the boundary between interpretation and amendment."98 Therefore, the Court of Appeal had gone too far when developing the new starring system. Under the Children Act 1989

92 Bellinger v Bellinger, above n 88, para 49 Lord Nicholls.

93 Re S (Care Order: Implementation of Care Plan) [2002] 2 WLR 720.

$94 \operatorname{Re} S$, above n 92, 726 para 17 Lord Nicholls.

$95 \operatorname{Re} S$, above n 92, 726 para 17 Lord Nicholls.

$96 \operatorname{Re} S$, above n 92, 730 para 35 Lord Nicholls.

$97 \operatorname{Re} S$, above n 92, 731 para 39 Lord Nicholls.

98 Re S, above n 92, 731 para 40 Lord Nicholls. See also $R v$ Lambert, above n 83, 575 para 79 Lord Hope: "But it is not for [the judges] to legislate. Section 3(1) preserves the sovereignty of Parliament. It does not give power to the judges to overrule decisions which the language of the statute shows have been taken on the very point at issue by the legislator". 
Parliament entrusted to local authorities, not to the courts, the responsibility for looking after children who are the subject of care orders. Lord Nicholls could not find any provision in the Children Act 1989 which lent itself to the interpretation that Parliament was conferring a supervisory function on the courts. The starring system, therefore, constituted an amendment of the Children Act 1989 not its interpretation. ${ }^{99}$ His Lordship also pointed out that the Court of Appeal's requirement that a formal report be produced, whenever a care plan was significantly departed from, was a matter for Parliament and not the courts to decide since it affected the whole manner in which authorities discharged their responsibilities. ${ }^{100}$

(d) Conclusion

In conclusion, therefore, the New Zealand Court of Appeal is, in comparison to the House of Lords, far more careful in regard to construction of statutory provisions. Second, the House of Lords has laid down some guidelines of how far statutory interpretation can go under section 3 of the Human Rights Act 1998 (UK), well aware that under the doctrine of parliamentary sovereignty it is not for the courts to make law. These guidelines can be used by the New Zealand Court of Appeal for guidance.

Furthermore, the critical discussion of the New Zealand Court of Appeal's Living Word Distributors $v$ Human Rights Action Group ${ }^{101}$ decision in the Inquiry into the Operation of the Films, Videos, and Publications Classification Act 1993 and Related Issues ${ }^{102}$ shows that the New Zealand Parliament is aware of judicial decision-making and is not afraid to discuss those decisions and remedy their effects.

\section{The doctrine of implied repeal}

The doctrine of implied repeal states that Parliament's latest intention prevails over previous ones. ${ }^{103}$ This doctrine is well established by English, ${ }^{104}$ Australian, ${ }^{105}$ and New Zealand ${ }^{106}$

$99 \operatorname{Re} S$, above n 92, 732 para 43 Lord Nicholls.

$100 \operatorname{Re} S$, above n 92, 732 paras 43-44 Lord Nicholls.

101 Living Word Distributors v Human Rights Action Group (Wellington) [2000] 3 NZLR 570; (2000) 6 HRNZ 28 (CA). In this case the Court of Appeal again needed to interpret the Films, Videos, and Publications Classification Act 1993. The Court took a narrow interpretation according to which videos "defaming" homosexuals with, inter alia, AIDS did not fall under the Act.

102 Report of the Government Administration Committee, above n 72, 14-15.

103 See Part III Parliamentary Sovereignty.

104 Ellen Street Estates Ltd v Minister of Health [1934] 1 KB 590 (CA).

105 South Eastern Drainage Board (SA) v Savings Bank of South Australia (1939) 62 CLR 603.

106 Patterson's Freehold Gold-dredging Co Ltd v Harvey (1909) 28 NZLR 1008 (SC). 
authority from the first half of the last century. The Canadian courts have stated that where there is an irreconcilable conflict between human rights legislation and other legislation, human rights legislation will prevail unless Parliament gave a clear indication in the inconsistent legislation that the legislation should prevail despite its inconsistency. ${ }^{107}$ However the House of Lords regarded European Community legislation as overriding later domestic legislation, by virtue of the principle of pre-eminence found in Community case law and required to be given effect to by section 2 of the European Communities Act 1972. The Court carefully considered whether the overriding status of Community law had been Parliament's intent. ${ }^{108}$ In a more recent judgment also concerning the question of the pre-eminence of European Community Law, Laws LJ refined this position and the doctrine of implied repeal. ${ }^{109}$ His Honour chose as a starting point the common law recognition of the existence of rights which can be classified as constitutional or fundamental citing cases like $R v$ Secretary of State for the Home Department, ex parte Simms. ${ }^{110}$ From this analysis follows, in Law LJ's view, a hierarchy of Acts of Parliament. Two categories of Acts exist, namely, ordinary and constitutional statutes. For a statute to be classified as constitutional it needs to "(a) [condition] the legal relationship between citizen and state in some general, overarching manner, or (b) [enlarge or diminish] the scope of what we would now regard as fundamental constitutional rights."111 The doctrine of implied repeal needs to be modified in regard to constitutional statutes. The test should be whether "it is shown that the legislature's actual - not-imputed, constructive or presumed intention was to effect the repeal or abrogation". ${ }^{112}$ In short: ${ }^{113}$

[A] constitutional statute can only be repealed, or amended in a way which significantly affects its provisions towards fundamental rights or otherwise the relation between citizen and state, by unambiguous words on the face of the later statute.

Having this latter refinement of the doctrine of implied repeal in mind, the New Zealand case law on implied repeal is of particular interest.

(a) New Zealand cases on implied repeal

$R v$ Poumako ("Poumako") was the first of two decisions dealing with the interpretation of the home invasion legislation passed in 1999. The issue revolved around whether a specific clause had

107 See, for example Re Winnipeg School Division (No 1) (1985) DLR (4 $4^{\text {th }}$ ) 1, 6 (SCC).

108 Ex parte Factortame Ltd [1990] 2 AC 85, 152-153 (HL).

109 Thoburn v Sunderland City Council [2003] QB 151.

$110 R v$ Secretary of State for the Home Department, ex parte Simms [2000] 2 AC 115, 131 (HL) Lord Hoffmann.

111 Thoburn v Sunderland City Council, above n 108, para 62.

112 Thoburn v Sunderland City Council, above n 108, para 63.

113 Thoburn v Sunderland City Council, above n 108, para 63. 
retrospective effect. The difference between the two cases lay in the different periods at issue. The Court found it desirable for Parliament to reconsider the issue holding that the legislation was inconsistent with fundamental rights. ${ }^{114}$ It also has to be noted that the provision at issue was introduced later in the legislative process and was not subject to a Bill of Rights Act section 7 report.

However, the majority (three to two) dealt with that issue only in obiter dicta, specifically stating that they did not need to reach a final conclusion, basing their decision on other grounds. In the obiter dictum, the majority found that it had never been Parliament's intent to afford retrospective effect to the home invasion provisions of the Crimes Act 1961. The judges interpreted the clause more narrowly, concluding that the section could be given retrospective effect only to the date on which the home invasion amendments to the Crimes Act 1961 commenced. Even though that would still conflict with the principle against sentences higher than at the time of offending, this interpretation was the most consistent with the rights and freedoms prescribed in the Bill of Rights Act and of those readings reasonably available. ${ }^{115}$

The dissenting judges on the other hand found that the section in question was unambiguous and certain in its retrospective effect and therefore section 6 of the Bill of Rights Act could not be invoked to support an interpretation which was not Parliament's intent (considered in the light of the parliamentary debates). ${ }^{116}$

In $R v$ Pora (Pora) $)^{117}$ a seven judge bench of the Court of Appeal, had to decide whether the 1999 amendment of the Criminal Justice Act, imposing a minimum of 13 years in detention where murder had been committed in the course of home invasion, would prevail retrospectively over the Criminal Justice Act 1985. In the 1985 Act Parliament had declared that no court could impose a retrospective penalty. It is important to note that all judges who dealt with the issue agreed that the interpretation problem facing the court did not relate to the meaning of either provision. Both provisions were clear in their meaning. All agreed that because the meaning of the provisions in question was clear and the provisions were irreconcilable, one had to yield to the other. The Court divided three to three on whether a fundamental right can be impliedly repealed by later legislation. ${ }^{118}$

$114 R v$ Poumako, above n 46, para 42 Richardson P, Gault and Keith JJ; para 67 Henry J; para 107 Thomas J.

$115 R v$ Poumako, above n 46, paras 36-41 Richardson P, Gault, Keith JJ.

$116 R v$ Poumako, above n 46, paras 57-58 Henry J; para 80 Thomas J.

$117 R \vee$ Pora, above $\mathrm{n}$ 21. See for a critical case note on $R v$ Pora: Andrew Butler "Implied Repeal, Parliamentary Sovereignty and Human Rights in New Zealand" [2001] PL 586.

118 Richardson P reserved his decision on that issue: $R v$ Pora, above n 21, para 60 Richardson P. 
Three of the judges took the view that, based on the long-standing rule of implied repeal, the Court must apply the statute that was enacted later in time and, therefore, the 1999 amendment of the Criminal Justice Act 1985 had retrospective effect. ${ }^{119}$ Those judges acknowledged that their interpretation of the provision in question was a serious breach of a fundamental rule of New Zealand's legal and constitutional system and New Zealand's international obligations.

The other three judges held that the predominant intention of Parliament may be found in the earlier statute, except where there is an express statement that the later Parliament intended to cease protecting the fundamental rights in question. ${ }^{120}$ They also pointed out that they were following Parliament's own intention, as manifested in section 6 of the Bill of Rights Act, that "Parliament must speak clearly if it wishes to trench upon fundamental rights." 121 Thomas J explicitly stated that where the courts are confronted with a difficult provision, "the Courts make do by filling the gap, if there be a gap, or by otherwise adopting an interpretation which accords with the purpose of the statute."122 Furthermore, they argued that through section 6 of the Bill of Rights Act Parliament had adopted a general principle of legality of the type acknowledged in a speech by Lord Hoffmann in $R$ $v$ Secretary of State for the Home Department, ex parte Simms and in other overseas case law. ${ }^{123}$ In his speech (referred to by the Court of Appeal judges) Lord Hoffmann acknowledged that parliamentary sovereignty meant that Parliament could legislate contrary to human rights. However, Parliament was constrained by the principle of legality which meant that it had to "squarely confront what it is doing and accept political cost". ${ }^{124}$

Both Pora and Poumako looked at the drafting history of the retrospective clause in the 1999 amendment. That history did not reveal any indication that Parliament appreciated that the adoption of the clause was inconsistent with the older provisions in the Criminal Justice Act 1985 which generally stated that courts could not impose sentences retrospectively, the Bill of Rights Act, and New Zealand's obligation under the International Covenant on Civil and Political Rights. Three judges viewed the doctrine of implied repeal as meaning that the provision in the amendment prevailed. Their Honours drew their conclusion from the text and the statement of the Member of Parliament promoting $\mathrm{it}^{125}$ and concluded that "Parliament's word and purpose are, we consider, so

$119 R$ v Pora, above n 21, paras 110-114 Gault, Keith, McGrath JJ.

$120 R v$ Pora, above n 21, para 20, 29, 52-53 and 56 Elias CJ and Tipping J; para 131 and 151 Thomas J.

$121 R v$ Pora, above n 21, para 52 Elias CJ and Tipping J; para 120 Thomas J.

$122 R v$ Pora, above n 21, para 122 Thomas J.

$123 R$ v Pora, above n 21, paras 53-56 Elias CJ and Tipping J.

$124 R v$ Secretary of State for the Home Department, ex parte Simms, above n 109, 131 Lord Hoffmann.

$125 R v$ Pora, above n 21, para 107 Gault, Keith and McGrath JJ. 
plain that we do not think that the breach can be removed by judicial interpretation."126 The other three judges held that it was: ${ }^{127}$

[I]nconceivable that Parliament would have acted so casually had it appreciated the implications [of the inconsistency with fundamental rights]. In the circumstances we do not accept that it is proper to draw an inference from the temporal sequence of the legislation or from the more specific terms of s 2(4) that Parliament intended it to prevail.

The Pora and Poumako judgments are more controversial in regard to whether the Court of Appeal was "judicially activist" by interpreting the legislation with a result orientated approach. That orientation assumed more or less openly that Parliament could not have wanted to fundamentally breach human rights either by holding that the earlier provision prevailed over the later or by giving the legislation a meaning which came to the "correct" result (but was otherwise strained). The English courts after Thoburn $v$ Sunderland City Council would have probably come to a similar result as the majority in Poumako and the "minority" in Pora. The provisions in regard to the retrospective amendment of the Criminal Justice Act 1985 are concerned with fundamental human rights as even the "majority" in Pora conceded. ${ }^{128}$ Therefore, the provisions have to be classified as fundamental and the "ordinary" doctrine of implied repeal would not be invoked. For the Amendment Act to repeal the provisions of the Criminal Justice Act 1985 an express repeal or an unambiguous wording would have been needed. Parliament has subsequently enacted section 6 of the Sentencing Act 2002 which clarifies that an offender has the right, if convicted of an offence in respect of which the penalty has been varied between the commission of the offence and sentencing, to benefit of the lesser penalty. ${ }^{129}$

(b) English jurisprudence

So far the English courts have not been faced with a situation comparable to Pora and Poumako. However, Anthony Bradley has stated that: ${ }^{130}$

[I]t is strongly arguable that the court must take into account the constitutional character of the [Human

Rights Act 1998], just as British courts have given special weight to [section] 2(4) of the European

$126 R v$ Pora, above n 21, para 116 Gault, Keith and McGrath JJ.

$127 R v$ Pora, above n 21, para 48 Elias CJ and Tipping J.

$128 R v$ Pora, above n 21, paras 110-114 Gault, Keith and McGrath JJ.

129 HSentencing and Parole Reform Bill 2002, no 148-2H (Justice and Electoral Committee report commentary, 12 February 2002) does not discuss retrospectivity of legislation. However, the inclusion of section 6 in the Sentencing Act 2002 indicates that Parliament had regard to the Court of Appeal's opinion in Poumako, above n 46 and Pora, above n 21. Parliament also repealed (with section 166(a) of the Sentencing Act 2002) section 80(a) of the controversial Amendment which had set out minimum periods of imprisonment.

130 Bradley, above n 4, 312. However, see Gearty, above n 7, 255 who argues that that approach would reduce parliamentary sovereignty. 
Communities Act 1972. This approach does not deprive Parliament of power to curtail human rights, but requires the clearest possible indication that Parliament intends to do so.

The House of Lords in a recent decision has generally emphasised that there is a presumption against the retrospective operation of legislation. This presumption is based on the principle that, unless a contrary intention was expressed, Parliament could not have intended to alter the law applicable to past events and transactions so as to alter the rights and obligations of the parties. ${ }^{131}$

(c) Conclusion

As Anthony Bradley has written and the House of Lords in Wilson v First County Trust Ltd (No 2) indicated, it is likely that a human rights consistent interpretation will be taken by the English courts unless Parliament has clearly stated otherwise. This argument is further strengthened by the decision in Thoburn $v$ Sunderland City Council. ${ }^{132}$ The New Zealand Court of Appeal has already applied the principle predicted by Anthony Bradley. A human rights consistent interpretation, however, can hardly be "activist" since New Zealand is a signatory to the international human rights instruments and is accordingly obliged by those instruments to adhere to international human rights principles. It is an established practice that New Zealand courts use international instruments for the interpretation of ambiguous terms in legislation. ${ }^{133}$ When interpreting ambiguous legislative terms, the courts work on the assumption that Parliament's intention would have been to comply with international human rights principles. Indeed, section 6 of the Bill of Rights Act gives a clear indication that whenever possible ambiguous terms should be interpreted in accordance with the Bill of Rights Act. Why should that established practice not also be used in regard to ambiguity of interrelationship of parts of a statute? In Pora and Poumako the Court had to take into account article 15(1) of the International Covenant on Civil and Political Rights which requires that no "heavier penalty be imposed than the one that was applicable at the time when the criminal offence was committed." For the benefit of a functioning government it was, one could argue, the Court's duty to take a human rights consistent approach and draw Parliament's attention to the effect its legislation had. Parliament's reaction by passing an additional amendment clarifying the 1999 amendment to the Criminal Justice Act 1985 shows that Parliament responds to decisions and concerns of the courts.

\section{CONCLUSION}

The abovementioned cases show that Parliament has not been deprived of its sovereignty by the courts. Generally, New Zealand judges are very aware that they are not to tread into Parliament's

131 Wilson v First County Trust Ltd (No 2) [2003] 3 WLR 568, para 18 (HL) Lord Nicholls.

132 Thoburn v Sunderland City Council, above n 108.

133 See for an overview of international human rights law by the New Zealand courts: Andrew Butler and Petra Butler "The Judicial Use of International Human Rights Law in New Zealand" (1998) 4 NZACL 173. 
arena. The courts can instead be understood as supplementing Parliament's intention by filling gaps in legislation and defining open terms rather carefully. However, Parliament has given up some of its moral power by allowing itself to be criticised by the courts either through declarations of inconsistency or when interpreting statutes by assuming Parliament intended to be consistent with the Bill of Rights Act. Moral power has considerable force because the body entrusted with it is required to exercise it with reference to legal standards and thereby generates stronger expectations as to compliance. However, Parliament already has experience with this kind of symbiosis in the Treaty of Waitangi field and the recommendations of the Waitangi Tribunal.

Ultimately, whether the courts have been "activist" depends on whether parliamentary sovereignty means that in the end Parliament has the last word and the courts are not allowed to create law contrary to a clearly stated parliamentary intention but are free to develop the law within the parameters created by statute. ${ }^{134}$ This paper has taken the view that this is New Zealand's constitutional reality. A reality which has, at least in the area of human rights, contributed to New Zealand's compliance with international human rights instruments. Therefore, at least if reliance was being placed on developments in the human rights field, section 3(2) of the Supreme Court Act 2003 was unnecessary.

134 As Sian Elias CJ assured the public recently, "Judges, in particular in a final appellate court, were subject to the law, limited by precedent, and the need to fit a case into the existing legal order": "Dame Sian and the Supremes" (20 March 2004) Dominion Post Wellington A19. See also Stephen Franks "Political Criticism of Judges" [2004] NZLJ 11. 